\title{
STRATEGI IMAGE EKSKLUSIF ISLAMIC BOARDING SCHOOL DALAM PENDIDIKAN KARAKTER AGAMA
}

\author{
Annisa Yutha, Hanny Hafiar. Centurion C. Priyatna \\ annisayutha@gmail.com; hannyhafiar@gmail.com \\ Universitas Padjadjaran
}

\begin{abstract}
Diniyyah Puteri Boarding School its a first female boarding school in Southeast Asia established in 1923. The present study was conducted to identify the public understanding which related to establishment od exclusive image with Diniyyah Puteri in implementing the religious character. In addition, it aims to recognize the exclusive image strategy of Diniyyah Puteri Boarding School and to understand the differentiation of implementing the religious character in Diniyyah Puteri Boarding School, Padang Panjang.The research method used was qualitative method with case study. The data collected by multiple technique, namely interview, observation, and literature review. Symbolic interaction theory and exclusive image concept become the theory basis to compose the research result. The result of research founded a particular processing of establishment of exclusive image on Diniyyah Puteri, Padang Panjang. In its process of image establishment, strategy of Diniyyah Puteri Padang Panjang is to use the difference approach between internal and external publics. In the end, its exclusive image applied and implemented in religious character education with the expected output as the student who has the main character, namely devout and good moral, strong and tough as Mujahid God, intelligent and skilled as God's steward.
\end{abstract}

\section{Keywords: Image, Exclusive Image, Islamic Boarding School, Education of Religious} Character.

\begin{abstract}
ABSTRAK
Diniyyah Puteri merupakan boarding school khusus wanita pertama di Asia Tenggara yang berdiri pada tahun 1923. Adapun tujuan penelitian ini adalah untuk mengetahui pemahaman public mengenai strategi image eksklusif Diniyyah Puteri Boarding School dalam penerapan pendidikan karakter agama, untuk mengetahui strategi yang digunakan untuk image ekslusif Diniyyah Puteri Boarding School, Padang Panjang, dan untuk mengetahui penerapan pendidikan karakter agama pada Diniyyah Puteri Boarding School, Padang Panjang yang membedakan dengan sekolah islam lainnya. Metode yang digunakan dalam penelitian ini adalah metode kualitatif dengan jenis penelitian studi kasus. Pengumpulan data dilakukan dengan cara wawancara, observasi, dan studi pustaka. Teori interaksi simbolik dan konsep image eksklusif menjadi landasan dalam membahas hasil penelitian. Hasil penelitian menunjukkan adanya proses strategi image eksklusif pada Diniyyah Puteri, Padang Panjang. Dalam proses pembentukan tersebut menggunakan strategi yang dibedakan antara pihak internal dan eksternal. Pada akhirnya image eksklusif tersebut diterapkan dalam pendidikan karakter agama, dimana output yang diharapkan, yaitu memiliki karakter utama yaitu: ahli ibadah dan akhlaqul karimah, kuat dan tegar sebagai mujahid Allah, cerdas dan terampil sebagai khalifah.
\end{abstract}

Kata kunci: Image, Eksklusif, Islamic Boarding School, Pendidikan Karakter Agama 


\section{PENDAHULUAN}

Diniyyah Puteri merupakan boarding school khusus perempuan pertama di Asia Tenggara yang didirikan pada tahun 1923. Seperti yang diketahui, masyarakat Minang menganut sistem matrilineal dalam alur keturunan. Pada masanya perempuan Minangkabau tidak dituntut untuk bersekolah tinggi karena mereka merupakan pemilik harta pusaka tinggi, mereka dituntut untuk mengurus keluarga daripada pendidikan. Menariknya, Diniyyah Puteri mendirikan sekolah khusus untuk perempuan di masa pendidikan dianggap tidak penting untuk perempuan, hal tersebut menjadikan Diniyyah Puteri eksklusif dibandingkan boarding school lainnya.

Biaya Diniyyah Puteri Boarding School untuk tingkat SMP tergolong mahal, yaitu 20 juta rupiah dengan biaya SPP bulanan 1.5 juta rupiah. Karena fasilitas yang ingin diberikan kepada siswa adalah yang terbaik, maka berbanding lurus dengan biaya pendidikan yang terbilang mahal. Walaupun biaya yang tergolong mahal, tidak menurunkan minat calon santri untuk bersekolah di Diniyyah Puteri, bahkan jumlah santri dari luar daerah Sumatera Barat lebih besar, yaitu 60$65 \%$ dari santri yang berasal dari Sumatera Barat sekitar 35-40\% (Bapak Rici tim pemasaran Diniyyah Puteri, wawancara, 24 Maret 2018). Tidak hanya luar daerah Sumatera
Barat, peminat Diniyyah Puteri juga sampai ke negara tetangga, Malaysia.

Pedagang sayuran di Jalan Raja Alang Kuala Lumpur Malaysia itu, Jum'at lalu pulang dari Kuala Lumpur hanya khusus mengantarkan anaknya mendaftar masuk ke perguruan Diniyyah Puteri Padang Panjang. "Saya pulang kampung bersama istri hanya mendampingi putri kami yang baru tamat sekolah dasar di Kuala Lumpur untuk melanjutkan pendidikan ke Perguruan Diniyyah Puteri Padang Panjang. Keinginan masuk ke Perguruan agama Diniyyah Puteri disamping harapan bagi kami yang sudah 10 tahun merantau di negara Jiran Malaysia itu juga atas minat putri kami yang menetapkan pilihan masuk ke Diniyyah Puteri, katanya kepada Haluan bertemu saat mereka mendaftar putrinya di Diniyyah Puteri, Jum'at lalu.

Ketika ditanya mengapa tidak di Malaysia saja melanjutkan pendidikan putrinya karena di negara Jiran itu banyak juga Perguruan agama. Namun katanya, Perguruan Diniyyah Puteri sudah tidak asing bagi warga Malaysia untuk tempat menimba ilmu agama karena sudah teruji, serta telah banyak melahirkan tokoh-tokoh di Nusantara dan di negara Malaysia sendiri, ungkapnya. (Tim Redaksi. 2016. Diniyyah Puteri Diminati di Malaysia. http://harianhaluan.com, $\quad 26$ September 2018). 
Persaingan dalam memenuhi kuota siswa pada sekolah Islamic Boarding School juga tidak bisa dimungkiri. Masing-masing sekolah swasta memiliki sistem pengajaran dan kurikulum yang berbeda, sehingga cara memasarkan sekolah pun dengan cara yang berbeda-beda pula. Persaingan untuk bisa menjadi santri di Diniyyah Puteri cukup tinggi, pada tahun 2017 peminat untuk masuk tingkat SMP ada 200 lebih calon santri, yang diterima hanya 100 orang, 50\% gagal untuk menjadi santri karena setiap tahun ada batasan jumlah santri yang diterima. (Hasil wawancara dengan Ibu Ria star administrasi Diniyyah Puteri, 24 Maret 2018). Salah seorang santri MA Diniyyah Puteri, Clara, merupakan calon santri yang gagal diterima pada saat akan mendaftar tingkat SMP 3 tahun yang lalu, akhirnya ia memutuskan untuk sekolah di boarding school lain, namun kembali mendaftar di Diniyyah Puteri untuk tingkat SMA dan akhirnya bisa menjadi santri Diniyyah Puteri. (Clara, wawancara, 17 Maret 2018).

Fakta dan data yang dipaparkan di atas menjadi landasan peneliti untuk mengetahui bagaimana strategi Image Eksklusif dalam menerapkan pendidikan karakter agama pada siswa oleh Diniyyah Puteri Boarding School, Padang Panjang. Sebagai literatur, Mead menempatkan bahwa, "Masyarakat pada kedudukan yang sangat penting, tetapi tak banyak membuat garis besar karakter masyarakat itu" (Poloma, 2003:254). Pusat perhatiannya tak lain adalah masalah-masalah filosofis. Mead didominasi oleh pandangan yang melihat realitas sosial sebagai proses ketimbang sebagai sesuatu yang statis. Manusia dalam proses sosial berada dalam proses akan jadi, bukan lagi sebagai fakta yang sudah lengkap (Poloma, 2003:256). George Herbert Mead dalam karya bukunya Mind, Self and Society menyumbangkan ide-ide dari teori interaksionisme simbolik.

Karya Mead yang paling terkenal ini menggarisbawahi tiga konsep kritis yang dibutuhkan dalam menyusun sebuah diskusi tentang teori interaksionisme simbolik. Tiga konsep ini saling memengaruhi satu sama lain dalam term interaksionisme simbolik. Dari itu, pikiran manusia (mind) dan interaksi sosial (diri/ self dengan yang lain) digunakan untuk mengintrepretasikan dan memediasi masyarakat (society) di mana kita hidup. Makna berasal dari interaksi dan tidak dari cara yang lain. Pada saat yang sama "pikiran" dan "diri" timbul dalam konteks sosial masyarakat. Pengaruh timbal balik antara masyarakat, pengalaman individu dan interaksi menjadi bahan bagi penelaahan dalam tradisi interaksionisme simbolik (Ardianto, 2010: 136).

Alasan peneliti menggunakan teori interaksi simbolik alam penelitian ini adalah, dalam teori 
interaksi simbolik oleh Mead menjelaskan bagaimana makna terbentuk melaui interaksi. Di mana makna tersebut dimaknai bersama oleh masyarakat atau disepakati bersama. Dalam penelitian ini mencoba untuk melihat bagaimana pemaknaan yang dihasilkan melalui Islamic Boarding School mengenai image eksklusif dan mencoba untuk membuat pengetahuan baru mengenai pendidikan karakter melalui nilai agama.

Dalam dunia Public Relations, fungsi dan peranan praktisi sangat dekat dengan image. Image atau citra merupakan salah satu cara untuk membentuk reputasi sebuah organisasi atau perusahaan. Definisi citra menurut Kotler (2005:607) menyatakan: "Image is the set beliefs, ideas, and impressions that a person hold regarding an object. People's attitude and actions towards an object are highly conditioned by that object's image". Dengan demikian, citra disebut sebagai seperangkat keyakinan, ide dan kesan yang dimiliki oleh seseorang terhadap suatu objek sangat ditentukan oleh citranya.

Sedangkan citra menurut Assael (1987:162) mengatakan adalah " An image is total perception of the subject that is formed by processing information from various sources overtime”. Maka, citra adalah keseluruhan persepsi dari suatu objek yang didapat melalui proses informasi dari berbagai sumber. Adapun menurut Aaker (1997:77) Citra adalah " The total impression of whatperson or group of people think and object". Sehingga citra dikatakan sebagai keseluruhan kesan dari suatu objek yang ditangkap oleh kelompok atau individu mengenai suatu hal. Dari beberapa pengertian di atas peneliti simpulkan bahwa image merupakan penilaian dari pihak ketiga yang disimpulkan berdasarkan apa yang mereka ketahui mengenai hal tersebut dari berbagai sumber.

Sedangkan eksklusif menurut KBBI memiliki pengertian khusus, sesuatu yang terpisah dengan yang lain. Adanya nilai tersendiri yang tidak dimiliki yang lain. Sehingga jika kita menggabungkan pengertian image eksklusif, yaitu keyakinan, ide dan kesan yang membentuk persepsi seseorang mengenai adanya suatu hal yang khusus dan berbeda dari yang lain.

Boarding School bukan sesuatu yang baru dalam konteks pendidikan di Indonesia. Karena sudah sejak lama lembaga-lembaga pendidikan di Indonesia menghadirkan konsep pendidikan Boarding

School yang mengadopsi "Pondok Pesantren". Boarding School adalah sekolah yang memiliki asrama, di mana para siswa hidup; belajar secara total di lingkungan sekolah. Karena itu segala jenis kebutuhan hidup dan kebutuhan belajar disediakan oleh sekolah (Maksudin, 2006:8) 
Prinsip-prinsip pendidikan islam dalam Boarding School pada umumnya sebagai berikut: a) Berupaya mengintegrasikan ayat qauliyah (ayat Al-quran) dan kaumiyah ayat tanda kebesaran Allah dalam alam semesta, iman dan ilmu, aspek fikriyah dan ruhiyah dengan jasadiayah yang diimplementasikan dalam pembelajaran dan hubungan sosial siswa. b) Dalam kegiatan kurikuler, kokurikuler, ekstrakulikuler, baik di sekolah, asrama dan lingkungan masyarakat yang dipantau oleh guru-guru selama 24 jam. Kesesuaian sistem boardingnya terletak pada semua aktivitas siswa yang diprogramkan, diatur dan dijadwalkan dengan jelas. c) aturan kelembagaannya sarat dengan muatan nilai-nilai moral.

Diniyyah Puteri Boarding School, Padang Panjang merupakan pesantren puteri pertama di Asia Tenggara (diniyyahputeri.org). Diniyyah Puteri Padang Panjang merupakan salah satu sekolah dengan lembaga pendidikan Islam modernis terbaik di Sumatera Barat sejak dahulu hingga sekarang. Salah satu pahalwan nasional, Rasuna Said, merupakan lulusan Diniyyah Puteri Padang Panjang. Alumni lainnya, yaitu Nurhayati Subakat yang merupakan CEO dari PT Paragon Technology and Innovation, sebuah perusahaan yang mengelola merk kosmetik Wardah, Make Over, dan perawatan rambut Putri dan IX. Lulusan Diniyyah Puteri pun banyak yang berhasil melanjutkan jenjang pendidikan ke Mesir seperti Universitas Cairo dan Al-Azhar. Lulusan dari Diniyyah Puteri Padang Panjang membuktikan bahwa tidak hanya ilmu agama yang dapat mereka kuasai, di dunia politik dan bisnis pun mereka dapat bersaing.

Menurut Darmiyati (2004:110) mendefinisikan pendidikan karakter sebagai sebuah usaha untuk mendidik anak-anak agar dapat mengambil keputusan dengan bijak dan mempraktikannya dalam kehidupan sehari-hari, sehingga mereka dapat memberikan kontribusi yang positif pada lingkungannya. Pendidikan karakter tidak melulu membahas bagaimana seorang anak harus pintar dan dapat memiliki kemampuan diatas rata-rata, namun jauh dari itu pendidikan karakter memiliki tujuan bagaimana pendidikan dapat diseimbangkan dengan sikap, nilai, perbuatan, moral, disiplin yang baik sehingga pendidikan dapat membentuk karakter kepribadian yang lebih baik bagi para pelajar.

Salah satu aspek penting dalam pendidikan karakter, yaitu agama. Agama banyak memberikan pengajaran yang baik dalam membentuk kepribadian seseorang, contohnya seorang anak akan bersikap santun terhadap orang yang lebih tua, itu karena orang tua mengajarkan kebaikan sejak dini kepada anaknya. Pengajaran orang tua pada anaknya merupakan syariat 
dalam beragama. Agama banyak memberikan ulasan mengenai pembentukan karakter yang baik. (Jannah, 2013).

\section{METODE PENELITIAN}

Menurut pemikiran Weber, paradigma konstruktivisme menilai perilaku manusia secara fundamental berbeda dengan perilaku alam, karena manusia bertindak sebagai agen yang mengonstruksi dalam realitas sosial mereka, baik itu melalui pemberian makna atau pemahaman perilaku dikalangan mereka sendiri.

\section{Konstruktivisme}

didefinisikan sebagai pembelajaran yang bersifat generatif, yaitu tindakan mencipta suatu makna dari apa yang dipelajari. Prinsip dasar konstruktivisme adalah bahwa tindakan ditentukan oleh konstruk diri sekaligus juga konstruk lingkungan luar dari diri. Menurut Ardianto dan Q Annes (2011:154), "Konstruktivisme merupakan salah satu filsafat pengetahuan yang menekankan bahwa pengetahuan individu adalah hasil konstruksi (bentukan) individu sendiri."

Metode yang digunakan
dalam penelitian ini adalah studi
kasus tunggal. Dalam tradisi
penelitian kualitatif dikenal
terminologi studi kasus (case study)
sebagai sebuah jenis penelitian. Studi
kasus terjadi ketika peneliti
melakukan eksplorasi terhadap
entitas atau fenomena tunggal (the
case) yang dibatasi oleh waktu,

Metode yang digunakan dalam penelitian ini adalah studi kasus tunggal. Dalam tradisi penelitian kualitatif dikenal terminologi studi kasus (case study) sebagai sebuah jenis penelitian. Studi kasus terjadi ketika peneliti melakukan eksplorasi terhadap case) yang dibatasi oleh waktu, aktivitas dan pengumpulan data selama waktu tersebut (Cresswel, 1994). Menurut Creswell (1998: 3738), "Fokus studi kasus adalah spesifikasi kasus dalam suatu kejadian, baik itu yang mencakup individu, kelompok budaya ataupun suatu potret kehidupan. Dikatakan studi kasus tunggal karena peneliti hanya menggunakan satu obyek atau satu kasus, yaitu image eksklusif pada Islamic Boarding School Diniyyah Puteri, Padang Panjang. Menururt Lincoln dan Guba (Dedy Mulyana, 2004:201) penggunaan studi kasus sebagai suatu metode penelitian kualitatif memiliki beberapa keuntungan, yaitu: a) Studi kasus dapat menyajikan pandangan dari subjek yang diteliti, b) Studi kasus menyajikan uraian yang menyeluruh yang mirip dengan apa yang dialami pembaca kehidupan sehari-hari. c) Studi kasus merupakan sarana efektif untuk menunjukkan hubungan antara peneliti dan responden. d) Studi kasus dapat memberikan uraian yang mendalam yang diperlukan bagi penilaian atau transferabilitas.

Menurut Bungin (2011:78) objek penelitian kualitatif menjelaskan objek penelitian yang fokus dan lokus penelitian, yaitu apa yang menjadi sasaran. Sedangkan informan penelitian adalah suyek penelitian yang memahami informasi obyek penelitian sebagai pelaku maupun orang lain yang memahami mengenai objek penelitian. 
Dalam penelitian ini, yang menjadi objek penelitian adalah strategi image eksklusif yang terbentuk di Diniyyah Puteri Boarding School, Padang Panjang untuk tingkat Madrasah Tsanawiah (MTs DMP) dan SMP. Tingkat MTs DMP dan SMP diambil karena memiliki image eksklusif yang lebih dari tingkat SMA MA. Jika seseorang atau orang tua rela mengeluarkan biaya yang cukup besar untuk tingkat MA SMA dianggap wajar karena menginginkan masuk perguruan tinggi terbaik. Namun, jika seseorang atau orang tua rela mengeluarkan biaya pendidikan lebih untuk tingkat MTs SMP maka sekolah tersebut memang memiliki image yang bagus.

Berdasarkan kriteria informan yang telah ditentukan dalam penelitian ini, maka peneliti memilih : Kepala divisi Humas Diniyyah Puteri Boarding School, Padang Panjang, Staf divisi Diniyyah Puteri Boarding School, Padang Panjang, Pengajar Madrasah Tsanawiah (MTs DMP) dan SMP Diniyyah Puteri Boarding School, Padang Panjang, Siswi Diniyyah Puteri Boarding School, Padang Panjang Madrasah Tsanawiah (MTs DMP) dan SMP, Orang tua siswi Madrasah Tsanawiah (MTs DMP) dan SMP, Tokoh masyarakat setempat, Masyarakat umum yang mengetahui mengetahui image eksklusif di Diniyyah Puteri.

Untuk memperoleh akses masuk ke dalam Diniyyah Puteri
Boarding School, Padang Panjang, peneliti mendapatkan rekomendasi dari Dinas Pendidikan Kota Padang Panjang Boarding School mana yang sesuai dengan kriteria penulis inginkan. Dengan menjelaskan kriteria boarding school yang memiliki keunikan, biaya pendidikan yang cukup mahal namun memiliki peminat yang tinggi, lalu pihak dinas pendidikan setempat merekomendasi Diniyyah Puteri sebagai objek penelitian.

Bentuk upaya untuk mendekatkan diri dengan informan kunci yang akan peneliti wawancara, yaitu melalui kepala Humas Diniyyah Puteri Boarding School, Padang Panjang, Ibu Rini. Setelah berkomunikasi secara langsung dan peneliti meminta bantuan dari Ibu Rini untuk meminta siapa saja informan yang bisa peneliti dapatkan baik pelajar aktif dan pengajar aktif. Dari data yang diberikan Humas, peneliti akan memilih siapa saja informan untuk penelitian ini.

$$
\text { Adapun teknik-teknik }
$$
pengumpulan data dalam penelitian ini adalah: Observasi, Wawancara Mendalam, Studi Pustaka. Guba dan Lincoln (dikutip dari Moleong, 2007:216) menjelaskan bahwa dokumen adalah setiap bahan tertulis ataupun film. Dokumentasi dalam penelitian ini diperlukan terutama untuk memperkaya landasanlandasan teoritis dan mempertajam analisis penelitian yang berkaitan dengan kajian implementasi image 
eksklusif. Teknik ini digunakan untuk memperoleh data dan informasi yang dibutuhkan dalam penelitian ini dengan cara studi pustaka dengan mengumpulkan informasi yang terdapat dalam artikel terkait, bukubuku, maupun karya ilmiah pada penelitian sebelumnya.

Creswell menjelaskan dalam bukunya mengenai analisis data dalam sebuah tabel (Creswell, 1998:148), namun peneliti akan membuat point-point dari tabel teknik analisis data dari Creswell: pada saat mengatur data, buat file dan atur file untuk data. Data tersebut dibaca maupun berupa teks, dapat pula membuat catatan marjin dan membentuk inisial kode. Kemudian setelah dibaca data tersebut digambarkan untuk menjelaskan kasus dan konteksnya. Dalam mengklasifikasikannya menggunakan agregasi kategoris serta menetapkan pola kategori. Untuk menginterpretasikannya dengan cara interpretasi langsung dan mengembangkan generalisasi naturalistic. Untuk mewakili visualisasi narasi perlu ditambah dengan tabel dan gambar

Pada penelitian ini, peneliti menggunakan teknik validitas data menggunakan triangulasi dengan sumber. Denzin dalam Moleong (2007: 330) "menjelaskan triangulasi dengan sumber sebagai, membandingkan dan mengecek balik derajat suatu informasi yang diperoleh melalui waktu dan alat yang berbeda dalam penelitian kualitatif." Dalam hal ini jangan sampai banyak mengharapkan bahwa hasil pembandingan tersebut merupakan kesamaan pandangan, pendapat, atau pemikiran yang penting adalah bisa mengetahui alasan-alasan terjadinya perbedaan tersebut. Triangulasi dengan sumber dapat dicapai dengan jalan: membandingkan data hasil pengamatan dengan hasil wawancara, membandingkan apa yang dikatakan orang di depan umum dengan apa yang dikatakannya secara pribadi, membandingkan apa yang dikatakan orang-orang tentang situasi penelitian dengan apa yang dikatakannya sepanjang waktu, membandingkan keadaan dan perspektif seseorang dengan berbagai pendapat dan pandangan orang seperti rakyat biasa, orang yang berpendidikan menengah dan tinggi, orang berada, atau orang pemerintahan, membandingkan hasil wawancara dengan isi dokumen yang berkaitan.

\section{HASIL DAN PEMBAHASAN}

Diniyyah Puteri Boarding School Padang Panjang, yang selanjutnya disebut Diniyyah Puteri merupakan salah satu Islamic Boarding School yang ada di Sumatera Barat, tepatnya di Kota Padang Panjang. Diniyyah Puteri beralamat di Jl. Abdul Hamid Hakim No.30, Ps. Usang, Padang Panjang Baru., Kota Padang Panjang, Sumatera Barat 27116. 
Kota Padang Panjang dijuluki kota Serambi Mekkah, karena dari zaman dahulu kota ini sudah menganut ajaran Islam dalam aturan kotanya, baik dari segi perdagangan hingga pendidikan, karena itu banyak sekolah islam bermunculan di kota Padang Panjang.

Kurikulum yang digunakan Diniyyah Puteri yaitu, $Q U B A$ Curriculum. QUBA merupakan singkatan dari Quran Sunnah, Brain, dan Attitude. Quba merupakan kurikulum integrasi yang saat ini diterapkan di Perguruan Diniyyah Puteri Padang Panjang. Artinya Al Quran dan Sunnah memimpin kerja otak (Brain), yang hasilnya terlihat dari sikap (Attitude). Kurikulum ini merupakan pengembangan lebih dalam dari Kurikulum 2013 dan dikombinasikan dengan kurikulum yang ada di Jepang dan Finlandia.
Kurikulum QUBA fokus untuk membentuk karakter santri tidak hanya pintar segi akademik tapi juga memiliki akhlak yang sesuai dengan quran dan sunnah. Kurikulum QUBA merupakan kurikulum integrasi yang menjadikan Al-Quran sebagai panduan hidup, dasar pengetahuan, sains, emosional, dan sosial dengan bimbingan teknis Hadist Nabi Muhammad SAW melalui pendekatan Neurosains. Kurikulum QUBA ini tidak sekedar pengembangan kemampuan kognitif dan daya hafalan anak saja, tapi juga fokus memperbaiki sikap anak dan membangun seluruh potensi otaknya. Alhasil nilai akademik akan berkembang pesat seiring dengan peningkatan wawasan dan karakternya.

\section{Tabel 1}

Rincian Biaya Masuk

\begin{tabular}{|l|l|l|l|}
\hline No & Biaya & \multicolumn{1}{l|}{ MTs DMP \& SMP } \\
\hline 1 & Pembangunan & & $\mathbf{1 0 . 0 0 0 . 0 0 0}$ \\
\hline 2 & Biaya Pendidikan Awal Tahun & & \\
\hline & Biaya Tahunan & 1.200 .000 & \\
\hline & Parenting & 2.000 .000 & \\
\hline & Pengembangan Bahasa & 200.000 & \\
\hline & Pustaka & 250.000 & \\
\hline & Kesehatan & 850.000 & \\
\hline & Eraining & 650.000 & \\
\hline & Anstrakulikuler & 200.000 & \\
\hline & Tes Peminatan & - & \\
\hline & MOS & 350.000 & \\
\hline & Buku & 1.000 .000 & $\mathbf{6 . 7 0 0 . 0 0 0}$ \\
\hline & & & \\
\hline & Biaya Perlengkapan & & \\
\hline & Seragam 3 stel & 1.200 .000 & \\
\hline & Dalaman Lilit 2 helai & 50.000 & \\
\hline & Baju Olahraga 1 stel & 250.000 & \\
\hline & Dalaman Rok 2 helsi & 150.000 & \\
\hline
\end{tabular}




\begin{tabular}{|l|l|l|l|}
\hline & & & $\mathbf{1 . 6 5 0 . 0 0 0}$ \\
\hline 3 & Biaya Bulanan & & \\
\hline & Makan & 625.000 & \\
\hline & Asrama & 400.000 & \\
\hline & SPP & 440.000 & \\
\hline & Komputer & 60.000 & \\
\hline & & & $\mathbf{1 . 5 2 5 . 0 0 0}$ \\
\hline & TOTAL & Rp 19.875.000 & \\
\hline
\end{tabular}

Sumber: diniyyahputeri.org

Berdasarkan hasil yang didapat, dalam menjalankan strategi image eksklusif Islamic Boarding School di Diniyyah Puteri, melibatkan dua pihak, yaitu public internal dan eksternal. Internal adalah pihak manajemen sekolah, santri, pengajar, sedangkan untuk pihak eksternal adalah masyarakat luas, calon santri, orang tua santri. Pemahaman publik internal mengenai strategi image eksklusif dianggap hal yang wajar dilakukan pihak manajemen, karena eksklusif yang santri dapatkan tidak melulu biaya pendidikan yang mahal, namun sebanding dengan fasilitas dan layanan yang mereka dapatkan. Publik eksternal pun juga menyatakan hal yang sejalan, bahwa strategi image eksklusif tersebut sudah cocok dengan hasil yang didapatkan. Baik masyarakat luas atau calon santri dan orang tau calon santri menganggap terciptanya nuansa eksklusif merupakan hal yang wajar, melihat program pendidikan yang diberikan pihak sekolah hingga keberhasilan alumni yang dianggap masyarakat luas sebagai salah satu hasil pendidikan di Diniyyah Puteri.
Strategi yang dijalankan pihak manajemen untuk publik eksternal dilakukan dengan cara terjun ke lapangan untuk mempromosikan keunggulan Diniyyah Puteri kepada calon santri dan calon orang tua santri, lalu memanfatkan media sosial untuk menyampaikan informasi terkait Diniyyah Puteri, dan memanfaatkan kekuatan alumni yang bisa membantu promosi secara tidak langsung. Sedangkan untuk public internal, strategi yang dilakukan bertujuan untuk meningkatkan kualitas pada Diniyyah Puteri seperti, meningkatkan kualitas pendidik, menonjolkan kurikulum, divisi otonom, program kegiatan dan pelatihan, fasilitas, dan ekstrakulikuler.

Hal ini berkaitan nantinya dengan penerapan pendidikan karakter agama pada Diniyyah Puteri Boarding School, Padang Panjang. Keberhasilan strategi image eksklusif ini akan terlihat apakah sesuai dengan pendidikan karakter yang dijalankan pihak manajemen. Kurikulum QUBA sebagai kurikulum andalan Diniyyah Puteri menjadi salah satu tolak ukurnya, apakah santri bisa lebih 
menonjolkan akhlak yang baik yang berpengaruh pada pembentukan sikap santri.

\section{A. Pemahaman Publik \\ Mengenai Image Eksklusif \\ Diniyyah Puteri Boarding School Padang Panjang}

Latar belakang kota Padang

Panjang sebagai kota Serambi Mekkah menjadi salah satu alasan banyaknya sekolah islam dan Boarding School berdiri. Beberapa diantaranya yaitu, Nurul Ikhlas Boarding School, Diniyyah Putera Padang Panjang, Serambi Mekkah Boarding School, Thawalib Boarding School, dan sekolah islam lainnya. Sistem asrama yang dijalankan Boarding School menjadi ciri khas sistem pendidikannya, setiap siswa atau santri dididik mandiri dan mampu menjalankan pelajaran tambahan mengenai ilmu agama. Fasilitas yang mereka dapatkan disesuaikan dengan setiap kegiatan yang akan mereka jalankan, mulai dari kebutuhan pribadi hingga kebutuhan pendidikan. Inilah salah satu alasan kenapa biaya pendidikan di Boarding School lebih mahal dari sekolah umum.

Diniyyah Puteri Boarding School Padang Panjang (yang selanjutnya ditulis dengan Diniyyah Puteri) merupakan Boarding School khusus wanita pertama di Asia Tenggara, dikenal dengan biaya pendidikan yang cukup tinggi jika dibandingkan dengan Boarding
School lainnya di Sumatera Barat. Biaya pendidikan yang cukup mahal inilah yang menjadi latar belakang munculnya Image Eksklusif di Diniyyah Puteri. Namun, walaupun biaya pendidikan yang cukup tinggi peminat untuk menjadi santri Diniyyah Puteri juga tinggi, yaitu sebesar $40 \%$ dari tahun lalu.

Strategi eksklusif pada Diniyyah Puteri terjadi begitu saja, tanpa ada keinginan khusus untuk membentuk image eksklusif, namun hal ini tercipta karena adanya sinergi antara apa yang diberi dan diterima selama santri belajar di Diniyyah Puteri. Peranan santri, guru, bahkan alumni sangat berpengaruh untuk membentuk anggapan masyarakat luas mengenai image tersebut. Diniyyah Puteri menganggap image yang terbentuk awalnya adalah hasil anggapan banyak masyarakat karena biaya pendidikan yang cukup mahal. Namun, image tersebut tidak dianggap negatif bagi Diniyyah Puteri, Diniyyah Puteri membuktikan dengan kualitas dan fasilitas yang mereka berikan kepada santri, agar santri dan orang tua santri dapat merasakan kepuasan layanan pendidikan.

Baik pihak manajemen Diniyyah Puteri maupun santri dan orang tua santri menyadari bahwa biaya pendidikan yang dikeluarkan cukup mahal dan terkesan eksklusif jika dibandingkan dengan sekolah lain, namun itu sebanding dengan yang didapatkan oleh santri. Dengan 
munculnya image eksklusif ini, Diniyyah Puteri menegaskan bahwa eksklusif yang diartikan tidak sebatas biaya yang mahal saja, namun eksklusif juga dalam segi program, fasilitas, sarana dan prasarana. Inilah yang menjadi nilai jual bagi Diniyyah Puteri untuk menyelaraskan image eksklusif yang ada.

Tidak hanya manajemen Diniyyah Puteri yang menyadari adanya image eksklusif, namun juga pihak eksternal seperti pihak pemerintah, media massa, orang tua santri dan masyarakat umum. Dapat disimpulkan dari berbagai narasumber yang didapatkan bahwa publik internal Diniyyah Puteri maupun eksternal menyadari adanya image eksklusif yang terbentuk di Diniyyah Puteri Padang Panjang. Namun, mereka menganggap hal tersebut adalah positif jika diiringi dengan layanan pendidikan yang diterima oleh santri. Biaya mahal tidak menjadi masalah jika dapat menjamin calon santri bisa menjadi santri yang pintar dan memiliki akhlak yang bagus.

Pentingnya citra perusahaan dikemukakan Gronroos dalam Sutisna (2001: 332) sebagai berikut: 1) menceritakan harapan bersama kampanye pemasaran eksternal, 2) sebagai penyaring yang memengaruhi persepsi pada kegiatan perusahaan, 3) sebagai fungsi dari pengalaman dan harapan konsumen atas kualitas pelayanan perusahaan, 4) mempunyai pengaruh penting terhadap manajemen atau dampak internal.

Jika dikaitkan dengan strategi image eksklusif pada Diniyyah Puteri Padang Panjang, 4 hal yang disampaikan oleh Gronroos, Diniyyah Puteri fokus pada poin dua hingga empat. Pada poin dua dijelaskan pentingnya image untuk penyaring yang mempengaruhi persepsi pada kegiatan perusahaan, maksudnya, Diniyyah Puteri fokus utamanya membentuk image positif yang natinya bisa mempengaruhi persepsi masyarakat luas bahwa eksklusif itu tidak sebatas harga mahal saja, tapi sebanding dengan kualitas yang diberikan.

Pada poin ketiga dijelaskan image itu fungsi dari pengalaman dan harapan konsumen atas kualitas pelayanan perusahaan. Dengan adanya penilaian yang baik dari masyarakat luas mengenai Diniyyah Puteri, tentunya masyarakat tersebut juga mempunyai harapan agar mutu sistem pendidikan lebih baik lagi, masyarakat mulai memiliki kepercayaan kepada Diniyyah Puteri dalam peningkatan mutu dan inovasiinovasi lainnya. Lalu pada poin terakhir image memiliki pengaruh penting terhadap manajemen atau dampak internal. Pihak manajemen berharap masyarakat dapat menilai eksklusif yang terbentuknya adalah sebanding dengan apa yang diberikan Diniyyah Puteri kepada santrinya, jika pihak internal dan eksternal sudah satu pemikiran mengenai 
image eksklusif maka Diniyyah Puteri akan memberikan perhatian lebih lagi untuk meningktakan mutu pendidikan, misal dengan menambah program unggulan, atau lebih meningkatkan mutu pengajar. Hal tersebut tentunya memengaruhi kebijakan yang telah ada sebelumnya.

Selain itu, dalam teori interaksi simbolik juga menjelaskan mengenai Mind, Self, and Society (Mulyana, 2001:68). Dalam tahapan strategi image eksklusif melibatkan mind. Goodman (2004:180-181) menjelaskan pikiran, yang didefenisikan Mead sebagai proses percakapan seseorang dengan dirinya sendiri, tidak ditemukan dalam diri individu; pikiran adalah fenomena sosial. Pikiran muncul dan berkembang dalam proses sosial dan merupakan bagian integral dari proses sosial. Proses sosial mendahului pikiran, proses sosial bukanlah produk dari pikiran. Karakteristik istimewa dari pikiran adalah kemampuan individu untuk memunculkan dalam dirinya tidak hanya satu respon saja, tetapi juga respon komunitas secara keseluruhan, itulah yang kita dinamakan pikiran. Dengan demikian pikiran dapat dibedakan dari konsep logis lain seperti konsep ingatan melalui kemampuannya menanggapi komunitas secara menyeluruh dan mengembangkan tanggapan terorganisir. Saat masyarakat umum termasuk calon santri dan orang tua calon santri menerima informasi mengenai Diniyyah Puteri, maka dalam diri mereka terjadi proses mind atau pikiran yang menerima simbolsimbol atau informasi-informasi mengenai Diniyyah Puteri.

Self, dalam teori interaksi simbolik Goodman (2004:180-181) menjelaskan, Self atau Diri berhubungan secara dialektis dengan pikiran. Artinya, disatu pihak Mead menyatakan bahwa tubuh bukanlah diri dan baru akan menjadi diri bila pikiran telah berkembang. Menurut Mead, diri adalah di mana orang memberikan tanggapan terhadap apa yang ia tujukan kepada orang lain dan di mana tanggapannya sendiri menjadi bagian dari tindakannya, di mana ia tidak hanya mendengarkan diri sendiri sebagaimana orang lain menjawab kepada dirinya, sehingga kita mempunyai perilaku di mana individu menjadi objek untuk dirinya sendiri. Karena itu, diri adalah aspek lain dari proses menyeluruh di mana individu adalah bagiannya. Dalam tahap self atau diri, masyarakat luas termasuk calon santri dan orang tua calon santri mulai melibatkan diri mereka untuk berfikir dan merespon informasi-informasi yang didapatkan mengenai Diniyyah Puteri. Pihak eksternal yang menilai dan memahami mengenai image eksklusif ini disebut society, Goodman (2004:180-181) menjelaskan Mead menggunakan istilah masyarakat (society) yang berarti proses sosial tanpa henti yang mendahului pikiran dan diri. Masyarakat memiliki peran 
penting dalam membentuk pikiran dan diri. Masyarakat mencerminkan sekumpulan tanggapan terorganisir yang diambil alih oleh individu dalam bentuk "aku" (me). Pihak eksternal merupakan pihak penting yang memberikan penilaian terhadap terbentuknya image eksklusif pada
Diniyyah Puteri, apa yang dilakukan oleh pihak internal untuk membentuk image positif dengan meningkatkan mutu pendidikan dan strategi lainnya dapat diterima dengan baik oleh masyarakat luas.

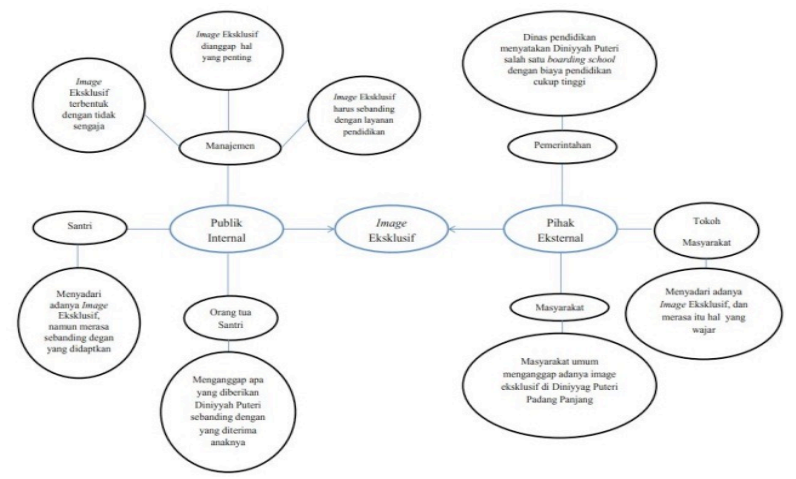

Gambar 1 Pemahaman Publik Mengenai Image Eksklusif Diniyyah Puteri Boarding School Padang Panjang

(Sumber: Hasil Penelitian 2018)

\section{B. Strategi Image Eksklusif Diniyyah Puteri Boarding School Padang Panjang}

Strategi Menurut J L Thompson (1995) yang dikutip dari Oliver (2007:2) mendefinisikan strategi sebagai cara untuk mencapai sebuah hasil akhir: hasil akhir menyangkut tujuan dan sasaran organisasi dan strategi kompetitif untuk masing-masing aktivitas. Hasil akhir yang ingin dicapai oleh Diniyyah Puteri Padang Panjang, yaitu masyarakat luas dapat tertarik dengan sistem pendidikan yang diberikan sehingga meningkatkan jumlah calon santri yang ingin bergabung di Diniyyah Puteri Padang
Panjang. Cara Diniyyah Puteri Padang panjang untuk mendapatkan hasil tersebut dengan mengklasifikasikan apa yang harus dilakukan secara internal dan eksternal.

Divisi Public Relations (PR) memiliki staf yang mempunyai fungsi dan peranan masing-masing. Administrasi memiliki tupoksi saat pendaftaran calon santri baru, dan melengkapi berkas-berkas administrasi selama masa pembelajaran di sekolah. Tim marketing fokus untuk meningkatkan penjualan dengan strategi yang telah ditentukan, sedangkan staf publikasi dan dokumentasi fokus dalam 
menjalankan fungsi media relations dan mengelola sosial media yang dimiliki oleh Diniyyah Puteri.

Untuk menjalankan strategi tersebut, Diniyyah Puteri memiliki strategi $P R$ untuk eksternal dan internal. Strategi eksternal yang dilakukan yaitu: 1) terjun ke lapangan untuk mensosialikasikan ke sekolahsekolah yang menjadi target Diniyyah Puteri Padang Panjang. 2) memanfaatkan media social seperti Website, Facebook, Youtube, Twitter, dan Instagram dalam menyebarkan informasi sesuai dengan kegunaan platform masing-masing. 3) kekuatan alumni. Ikatan Keluarga Diniyyah Puteri atau disebut IKD memiliki struktur organisasi sendiri yang dikelola dengan baik oleh para alumni. Pihak Diniyyah Puteri selalu memantau perkembangan dan kegiatan apa saja yang dilakukan oleh IKD, walaupun demikian pihak sekolah tidak mengatur $100 \%$ apa saja program yang akan djalankan IKD. Banyak calon santri yang mendaftar ke Diniyyah Puteri karena mendapatkan informasi dari para alumni, baik alumni tersebut adalah anggota keluarga mereka atau bukan.

Tim pemasaran yang berada di bawah divisi Public Relations pada tahap awal akan mendata sekolah apa saja yang menjadi "pasar" Diniyyah Puteri. Terjun ke lapangan biasanya melakukan sosialisasi ke sekolahsekolah pilihan dan mengenalkan Diniyyah Puteri kepada siswa sekolah tersebut. Sekolah yang dipilih dengan kategori: alumni sekolah tersebut banyak yang menjadi santri Diniyyah Puteri, sekolah tersebut merupakan sekolah-sekolah terbaik di daerahnya, sekolah tersebut merupakan sekolah islam terpadu. Sosialisasi ke sekolah ini dilakukan di berbagai daerah, tidak hanya di Sumatera Barat saja, karena santri Diniyyah Puteri lebih dari 50\% merupakan santri dari luar daerah Sumatera Barat.

Strategi presentasi untuk tingkat SD dan SMP tentu berbeda, untuk SD tim pemasaran Diniyyah Puteri lebih mengandalkan dengan bercerita, atau melihatkan tayangan video yang dapat menarik minat mereka. Sedangkan untuk tingkat SMP, tim pemasaran akan melihat mood siswa terlebih dahulu, apakah mereka lebih menginginkan presentasi yang manarik atau mereka adalah siswa yang lebih suka jika dipaparkan dengan cita-cita dan masa depan. Setelah sosialisasi dilakukan, tim pemasaran akan berkoordinasi dengan pihak sekolah untuk tindak lanjut jika ada siswa yang ingin mendaftar menjadi santri Diniyyah Puteri. Setelah itu, hasil sosialisasi akan dibuatkan dalam bentuk laporan kegiatan yang akan dipertanggungjawabkan langsung kepada pimpinan Diniyyah Puteri. Jika dari hasil laporan tersebut sekolah yang dikunjungi memberikan respon positif, akan diberikan perhatian khusus untuk tahapan selanjutnya. 
Diniyyah Puteri sangat aktif dalam memanfaatkan media sosial, terbukti dalam strategi pemasaran yang dilakukan, Diniyyah Puteri sudah tidak lagi menggunakan cara yang konvensional seperti membuat spanduk pendaftaran siswa baru. Tim $P R$ Diniyyah Puteri media sosial sudah menggantikan peranan pemasaran secara konvensional bahkan lebih efektif.

Diniyyah Puteri memiliki beberapa platform, seperti Facebook, Youtube, Website, dan Twitter. Setiap platform tersebut memiliki peranan yang berbeda. Setiap konten yang diberikan disesuaikan dengan keunggulan platform tersebut, Tim $P R$ Diniyyah Puteri memiliki staf khusus untuk publikasi dan dokumentasi yang salah satu fungsinya mengatur penggunaan media sosial.

Website. Website Diniyyah Puteri merupakan platform utama dalam menjalankan pemasaran melalui media sosial. Konten website berisi kumpulan informasi yang memudahkan calon santri untuk melihat gambaran bagaimana bersekolah di Diniyyah Puteri. Konten tersebut mulai dari profil sekolah, program pendidikan, divisi otonom yang dimiliki, cara pendaftaran, fasilitas yang dimiliki, hingga kontak yang dapat dihubungi. Dalam website ini juga berisi tulisan para santri yang diwadahi divisi otonom Diniyyah Research Center.
Bagi calon santri khususnya di luar daerah Sumatera Barat, lebih sering mencari informasi mengenai Diniyyah Puteri melalui website. Informasi mengenai syarat pendaftaran hingga biaya pendidikan disediakan di website tersebut. Selain itu, dengan adanya informasi mengenai lingkungan sekolah akan memudahkan untuk calon santri dan orang tua calon santri untuk mendapatkan gambaran lingkungan sekolah. Konten website Diniyyah Puteri dikelola oleh tim publikasi dan dokumentasi, setiap adanya informasi terbaru mengenai Diniyyah Puteri akan unduh ke laman website.

Facebook. Platform kedua yang dimanfaatkan Diniyyah Puteri, yaitu Facebook. Pengelola akun Facebook tersebut juga dikelola oleh tim publikasi dan dokumentasi. Konten untuk Facebook lebih membagikan informasi terkini mengenai perkembangan Diniyyah Puteri. Informasi mengenai kegiatan penting, seperti training yang dilakukan baik untuk internal maupun eksternal, hingga membagikan informasi suasana di sekolah, misalnya suasana saat hari pertama di asrama yang dikemas dengan cerita yang menarik.

Laman Facebook ini cukup interaktif untuk sesama anggota grup, khususnya para alumni yang ingin bernostalgia dengan suasana Diniyyah Puteri. Banyak alumni yang ikut berkomentar dengan membagikan kisah mereka di saat 
masih menjadi santri. Calon santri yang ingin bertanya seputar Diniyyah Puteri juga bias ikut berkomentar, para alumni dan admin akan membantu setiap pertanyaan yang diberikan.

Informasi yang banyak
menarik minat anggota grup Facebook adalah informasi terobosan baru yang dilakukan oleh pihak Diniyyah Puteri, misalnya kerja sama dengan perguruan tinggi luar negeri, informasi mengenai kunjungan santri ke berbagai perguruan tinggi dalam dan luar negeri. Facebook masih dianggap efektif dalam menjalankan pemasaran bagi pihak Diniyyah Puteri.

Youtube. Sesuai dengan fungsi platform Youtube, yaitu konten yang dikemas dengan format video. Diniyyah Puteri memanfaatkan Youtube untuk membagikan kegiatan apa saja yang telah dilakukan. Bagi santri, calon santri, dan orang tua santri yang telah membaca informasi seputar Diniyyah Puteri melalui website misalnya, mungkin merasa belum bisa membayangkan secara nyata bagaimana suasana tersebut, maka dengan melihat video yang diunggah melalui Youtube mereka dapat melihat secara nyata bagaimana lingkungan sekolah, apa saja kegiatan yang dilakukan, dan video menarik lainnya yang akan menambah keinginan calon santri bergabung dengan Diniyyah Puteri.

Twitter. Twitter dimanfaatkan Diniyyah Puteri untuk memberikan informasi secara singkat dan cepat. Misalnya saat memberikan informasi secara "live" mengenai acara yang sedang berlangsung. Informasi yang disebar di platform lain juga bisa diakses melalui Twitter, yaitu dengan menggunakan fitur "link to Twitter", jadi informasi tersebut bisa tersebar di dua platform sekaligus dalam satu waktu. Jika dibandingkan dengan Facebook, Twitter tidak begitu interaktif dengan pengikutnya. Pengelola akun hanya sebatas membagikan informasi saja.

Instagram.

Platform

Instagram merupakan salah satu media sosial yang sedang tren saat ini, setiap pemilik akun mengunggah konten foto semenarik mungkin. Namun, bagi Diniyyah Puteri tren tersebut ternyata tidak begitu efektif dalam segi pemasaran. Jika dibandingkan dengan media sosial Diniyyah Puteri lainnya, Instagram adalah platform yang informasinya kurang "up date", terlihat postingan terakhir, yaitu pada tahun 2017. Konten dalam akun Instagram berisi foto-foto kegiatan baik di lingkungan sekolah atau kegiatan di luar, foto tersebut disertai informasi yang menjelaskan kegiatan yang berlangsung.

Sedangkan untuk strategi internal yang dilakukan: 1) meningkatkan mutu pengajar: Menurut Kunandar (2007:76) komponen guru yang berkompetensi profesional diantaranya: a) menguasai substansi keilmuan yang 
terkait dengan bidang studi. b) menguasai struktur dan metode keilmuan. Tim pengajar Diniyyah Puteri sudah sesuai dengan konsep pengajar dengan kompetensi profesional. Tenaga pengajar juga sering diikutsertakan dalam pelatihan peningkatan kompetensi guru, salah satunya pelatihan dalam kurikulum QUBA.

Kurangnya SDM yang dimiliki sehingga minimnya analisis situasi di lapangan (Pakaradena, Hafiar, dan Nugraha, 2018). Oleh karena itu, sebelum dimulainya tahun ajaran baru di setiap semesternya, semua guru, karyawan, dan petugas asrama diberikan pelatihan tentang kurikulum $Q U B A$ tersebut. Sebab, organisasi atau perusahaan harus ada beberapa aspek yang diperhatikan, yaitu lingkungan internal (Putri, Utami, Dida, Ari, \& Prastowo, 2017).

Pelatihan ini berisi tentang bagaimana menerapkan kurikulum dengan baik, mengevaluasi perjalanan kurikulum ini satu semester sebelumnya, dan melakukan inovasi-inovasi terbaru untuk pengajaran berikutnya. 2) kurikulum: Diniyyah Puteri Padang Panjang mengkolaborasikan tiga kurikulum (kurikulum kementerian agama, kurikulum kementerian pendidikan, dan kurikulum Diniyyah Puteri Padang Panjang) yang diterapkan melalui multiple intelligence, membuat santri tidak canggung untuk mengembangkan diri mereka, dengan modal pembinaan karakter yang baik, mereka mampu untuk bersikap lebih dewasa terdiri diri sendiri. 3) mempunyai pihak eksternal di luar pengajar untuk ikut mengawasi para santri, yakni adanya divisi otonom, program unggulan dan training yang diberikan kepada santri bahkan hingga ke luar negeri, ektrakulikuler dan organisasi untuk menyeimbangkan kegiatan beajar para santri, dan didukung dengan fasilitas yang baik untuk menjalani proses belajar mengajar di sekolah dan asrama.

Oleh sebab itu, diperlukan pula publikasi terhadap pihak internal dengan menyebarkan informasi tentang lembaga melalui brosur atau koran internal, annual meeting, atau dengan workshop dan media komunikasi lainnya (Sholihat, Perbawasari, dan Lukman, 2018). Tiga konsep teori interaksi simbolik yang dijelaskan Goodman (2004:180181) yaitu mind, self, dan society pada tahap strategi image eksklusif melibatkan ketiga konsep tersebut. Strategi internal yang dilakukan Diniyyah Puteri mendukung strategi eksternal, jika strategi internal berhasil yaitu kualitas meningkat maka strategi eksternal lebih mudah dilaksanakan.

Saat seseorang atau masyarakat umum menjadi sasaran strategi tersebut dan menerima informasinya maka mind akan mulai menerima rangsangan, ada symbol yang diterima saat mendapat terpaan strategi eksternal, misalnya saat 
mendengarkan sosialisasi yang dilakukan oleh tim pemasaran Diniyyah Puteri Padang Panjang. Saat mind mulai memengaruhi diri untuk mempercayai apa yang diterimanya, strategi tersebut berhasil maka self mulai terlibat dalam mengambil keputusan. Pada akhirnya society mengumpulkan semua persepsi yang dihasilkan dan mendapat terpaan strategi tersebut.

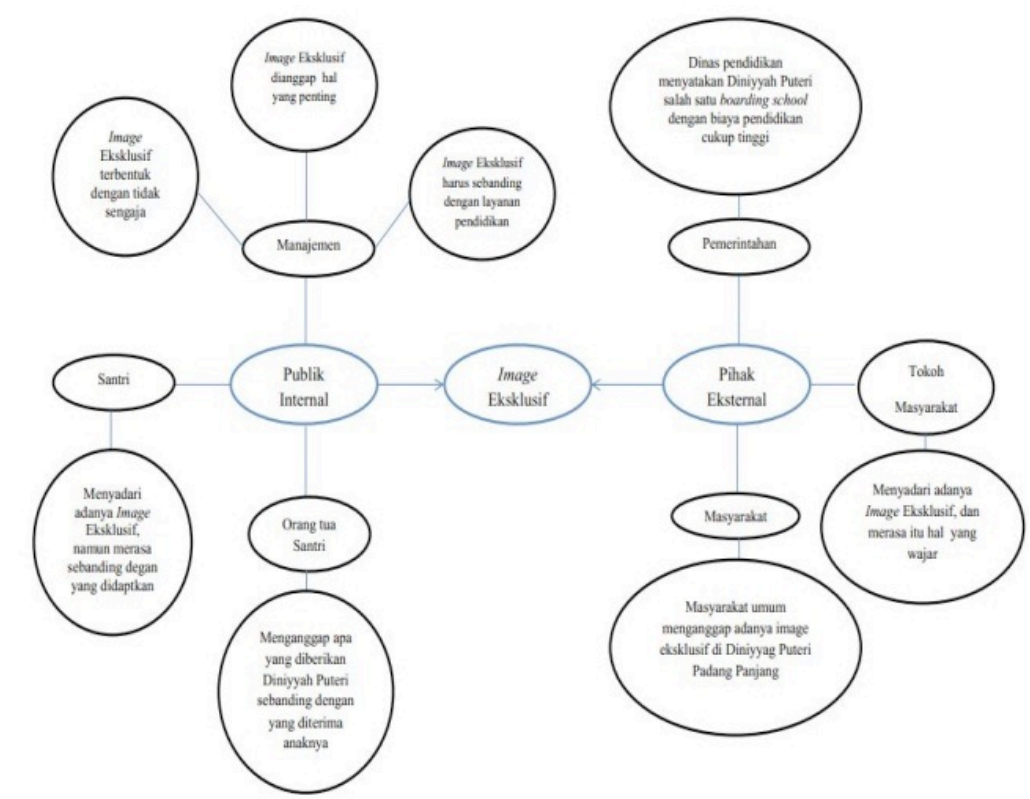

\section{Gambar 2 Strategi Image Eksklusif Diniyyah Puteri Boarding School Padang Panjang}

\section{Penerapan Pendidikan \\ Karakter Agama di Diniyyah Puteri Padang Panjang}

Hasil akhir dari proses pembelajaran di Diniyyah Puteri, yaitu karakter yang dimiliki masingmasing santri, dan hal tersebut juga yang diharapakan dalam hasil image eksklusif. Diniyyah Puteri Padang Panjang berharap karakter yang dibentuk pada santri bisa menjadi image eksklusif bagi sekolah dan bisa diterapkan dalam kehidupan seharihari, sesuai dengan yang dijelaskan
Darmiyati (2004: 110) yang mendefinisikan pendidikan karakter sebagai "Sebuah usaha untuk mendidik anak-anak agar dapat mengambil keputusan dengan bijak dan mempraktikannya dalam kehidupan sehari-hari, sehingga mereka dapat memberikan kontribusi yang positif pada lingkungannya".

Pendidikan karakter agama merupakan pendidikan karakter dalam Islam, yaitu identik dengan pendidikan etika atau adab lahir dan batin. Ini dapat dimaknai pada sebuah tujuan pendidikan yang bermuara 
pada pembentukan moral. Sehingga dapat disimpulkan bahwa pengertian pembentukan moral atau etika diartikan sama dengan pembentukan karakter. Setiawan (2014:Vol 1). Sistem pendidikan Diniyyah Puteri Padang Panjang yang menrapkan kurikulum $Q U B A$ sangat berpegang teguh pada pendidikan karakter agama. Hasil akhir yang diinginkan dalam proses pembelajaran ini ada tiga karakter utama, yaitu: ahli ibadah dan akhlaqul karimah, kuat dan tegar sebagai mujahid Allah, cerdas dan terampil sebagai khalifah.

Dalam kurikulum $Q U B A$, nilai sikap lebih penting dari nilai akademik. Jika nilai akademik bagus, namun sikap kurang maka bisa saja tidak naik kelas atau tidak lulus. Bahkan hingga santri menjadi alumni, sikap mereka akan tetap dipantau. Ini yang menjadikan tujuan utama Diniyyah Puteri menghasilkan santri dengan sikap dan akhlak baik sehingga masa depan mereka sudah dibekali dengan agama yang kuat.

Penerapan kurikulum $Q U B A$ untuk membentuk karakter utama dimulai dari tahap awal penerimaan calon santri, tes ujian masuk berupa tes tertulis untuk memetakan dan mempelajari perkembangan otak masing-masing santri guna keberlanjutan pembinaan karakter di kemudian hari setelah memasuki sekolah. Setelah santri diterima, mereka akan menandatangani kontrak belajar yang berisikan jadwal kegiatan mereka dari bangun tidur hingga tidur lagi. Komitmen kontrak belajar tesebut tidak hanya untuk santri, tapi juga orang tua santri, menyatakan bahwa perlunya kerja sama orang tua dalam membentuk karakter anak, orang tua harus berkomitmen mendukung program sekolah. Pelaksanaan kurikulum QUBA berkaitan dengan kegiatan agama selama di sekolah dan asrama. Setiap pagi menjelang pelajaran dimulai, seluruh santri diinstruksikan untuk shalat dhuha, guna untuk mendidik santri agar dapat menunaikan kewajiban walaupun sesibuk apapun.

Wali kelas sangat berperan penting dalam membentuk karakter santri ketika di sekolah, wali kelas selalu mendampingi santri dan menjadi tempat pengaduan ketika berada di sekolah. Nantinya wali kelas akan berdiskusi dengan umi asrama dalam menilai perkembangan anak. Selain wali kelas divisi otonom juga berperan dalam memantau perkembangan santri.

Untuk menunjang pembentukan karakter utama, divisi otonom tahfizul bertanggung jawab dalam membina hafalan santri. Untuk tingkat MTs SMP ditargetkan minimal 4 juz, hafalan tersebut disetor ke umi asrama, dan bisa ditangguhkan jika masih belum lancar. Divisi otonom English dan Arabic Center juga berperan dalam proses pembentukan karakter. Bahasa yang digunakan dalam kegiatan sehari-hari adalah Arab dan Inggris 
keduanya bergantian setiap minggunya. Melalui penggunaan bahasa ini, asrama secara tidak langsung mendidik kedisiplinan dan kerja keras santri, karena mustahil dapat berbicara dengan bahasa asing jika tidak belajar dengan giat.

Berdasarkan tahapan yang telah penulis lakukan mulai dari pengumpulan sampai pada pengolahan data dapat diperoleh kesimpulan sebagai berikut: Image eksklusif pada Islamic Boarding School sering dikaitkan dengan biaya pendidikan yang mahal. Salah satu faktor penyebabnya komersialisasi dalam pendidikan Islam mendorong munculnya pesantren modern. Perkembangan di zaman milenium ini menuntut masyarakat untuk mampu hidup dengan berbagai kecanggihan teknologi, berwawasan global, serta berakhlak baik. Akan tetapi, secara sadar masyarakat juga membutuhkan agama sebagai sarana pendidikan agar seseorang mampu menjadi sosok yang berakhlak baik, dan berlaku secara benar menurut ajaran dan kepercayaannya. Hal tersebut membuat permintaan masyarakat menjadi tinggi karena menjadi sosok yang modern dan unggul dalam keislaman.

Namun, keterbatasan pada sumber daya manusia yang paham dan mampu mengajarkan ilmu pengetahuan umum, agama dan perkembangan teknologi secara bersamaan. Sehingga orang berlomba menciptakan lembaga pendidikan dengan pengetahuan umum yang baik, agama yang baik dan teknologi. Perubahan masyarakat khususnya perkotaan dengan status sosial ekonomi menengah ke atas membutuhkan suatu pendidikan yang modern, lengkap, profesional namun tidak meninggalkan pula modal spiritual/agamanya.

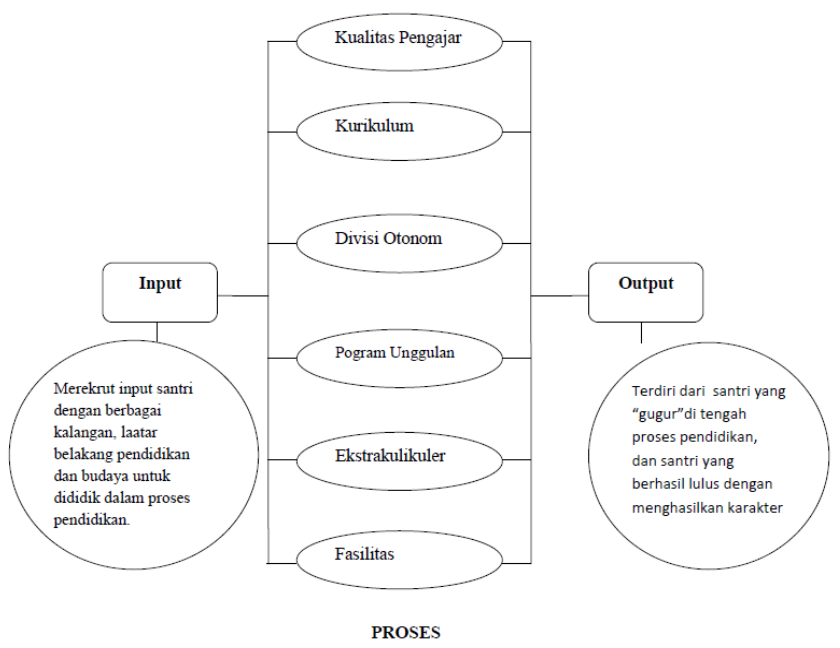

Gambar 3 Penerapan pendidikan karakter agama di Diniyyah Puteri Padang Panjang

(Sumber: Hasil Penelitian 2018) 


\section{SIMPULAN}

Image eksklusif muncul dari kesan dan penilaian masyarakat luas. Publik internal Diniyyah Puteri maupun eksternal menyadari adanya image eksklusif yang terbentuk di Diniyyah Puteri Padang Panjang. Namun, mereka menganggap hal tersebut adalah positif jika diiringi dengan layanan pendidikan yang diterima oleh santri. Biaya mahal tidak menjadi masalah jika dapat menjamin calon santri bisa menjadi santri yang pintar dan memiliki akhlak yang bagus.

Diniyyah Puteri Padang

Panjang menganggap image eksklusif adalah hal yang penting dan harus diperhatikan, namun tidak boleh menjadikan itu hal utama. Strategi yang dilakukan dalam image eksklusif ada dua, strategi untuk publik internal dan eksternal. Strategi untuk publik internal bertujuan untuk meningkatkan kualitas sistem pendidikan yang ada di Diniyyah Puteri Padang Panjang. Cara meningkatkan kualitas, yaitu meningkatkan kualitas pengajar, membentuk kurikulum yang baik, mempunyai pihak eksternal di luar pengajar untuk ikut mengawasi para santri, yakni adanya divisi otonom, program unggulan dan training yang diberikan kepada santri bahkan hingga ke luar negeri, ekstrakulikuler dan organisasi untuk menyeimbangkan kegiatan belajar para santri, dan didukung dengan fasilitas yang baik untuk menjalani proses belajar mengajar di sekolah dan asrama.

Sedangkan strategi untuk publik eksternal dilakukan dengan tiga cara yaitu, melakukan publisitas dengan terjun langsung ke sekolah untuk melakukan sosialisasi ke Sekolah Dasar yang sesuai dengan kriteria ditentukan, dimana sosialisasi tersebut nantinya akan dievaluasi apakah sesuai target atau indak. Lalu yang kedua dengan memanfaatkan media sosial tim publikasi dan dokumentasi yang berada di divisi public relations memanfaatkan media social sebagai platform dalam menyampaikan informasi seputar Diniyyah Puteri Padang Panjang, karena tim pemasaran menganggap iklan tidak terlalu efektif dalam meningkatkan pemasaran, media social lebih menjanjikan dengan banyaknya pilihan platform, mulai dari Website, Facebook, Twitter, Youtube, dan Instagram, yang bisa digunakan berdasarkan fungsi platform masing-masing.

Ketiga strategi eksternal, yaitu kekuatan alumni, Diniyyah Puteri Padang Panjang memiliki ikatan alumni yang kuat dan berpengaruh. Mereka memiliki ikatan persaudaraan yang tinggi dikarenakan hidup bersama-sama selama di asrama dan di sekolah, sehingga secara tidak sadar alumni menjadi peran penting 
dalam memasarkan Diniyyah Puteri Padang Panjang.

Penerapan pendidikan

karakter agama di Diniyyah Puteri Padang Panjang dinilai baik. Dengan menggunakan tiga kurikulum (kurikulum kementerian agama, kurikulum kementerian pendidikan, dan kurikulum Diniyyah Puteri Padang Panjang), pihak manajemen mengkolaborasikan kurikulum tersebut untuk diterapkan kepada santri, bahwa yang terpenting dalam pendidikan itu bukan nilai akademik tapi akhlak. Akhlak yang baik bisa menjadi modal utama menjadi orang yang sukses nantinya.

Proses pembentukan karakter agama ini terdiri dari tiga tahap. Pertama input, bagaimana Diniyyah Puteri Padang Panjang merekrut input santri dari berbagai kalangan, latar belakang pendidikan dan budaya. Lalu tahapan proses semua strategi internal dilakukan untuk meningkatkan kualitas pendidikan kepada santri dengan harapan santri bisa menjadi seseorang yang pintar dan berakhlak. Terakhir tahapan output, ada santri yang gagal di tengah perjalanan pendidikan karena merasa tidak sanggup atau tidak sesuai dengan keinginannya, ada juga santri yang berhasil dan lulus bisa mengaplikasi tiga karakter utama yaitu: ahli ibadah dan akhlaqul karimah, kuat dan tegar sebagai Mujahid Allah, Cerdas dan terampil sebagai khalifah.

\section{DAFTAR PUSTAKA}

Buku:

Aaker, David. 1997. Manajemen Ekuitas Merek. Jakarta: Spektrum.

Ardianto, Elvinaro et al. 2004. Dasardasar Public Relations. Bandung: Remaja Rosdakarya.

Assael, Henry. 1987. Consumer Behavior and Marketing Action, Fourth Edition PWS. Boston: Kent Publishing Company.

Bungin, Burhan. 2011. Metodologi Penelitian Kualitatif (Aktualisasi Metodologi ke Arah Ragam Varian Kontemporer). Jakarta: Raja Grafindo Persada.

Creswell, John W. 1998, Qualitative Inquiry and Research Design, Choosing Among Five Traditions. California: Sage Publication

Darmiyati, Zuhdi. 2004, Pendidikan Humanism. Jakarta: Bumi Aksara.

Goodman, Douglas dan George Ritzer. 2004. Teori Sosiologi Modern. Jakarta: Prenada Media.

Kotler, Philip. 2005. Manajamen Pemasaran, Jilid 1 dan 2. Jakarta: PT. Indeks Kelompok Gramedia.

Kunandar. 2007. Guru Profesional : Implementasi Kurikulum Tingkat Satuan Pendidikan (KTSP) dan Sukses dalam Sertifikasi Guru. Jakarta: Rajagrafindo Persada.

Maksudin. 2006. Pendidikan Nilai Sistem Boarding School di SMP IT Abu Bakar (Hasil Penelitian Untuk Disertasi). Yogyakarta: 
Program Pasca Sarjana UIN

Sunan Kalijaga.

Oliver, Sandra. 2007. Strategi Public

Relations.

Bandung:

Erlangga.

Sutisna. 2001. Perilaku Konsumen

dan Komunikasi Pemasaran.

Bandung: PT. Remaja

Rosdakarya. 
Sumber lain :

Diniyyahputeri. 2018. Profil Sejarah Diniyyah Puteri. Diakses 9 Januari 2018, dari http://www.diniyyahputeri.or g/index.php/profil/sejarah

Diniyyahputeri. 2018. Visi dan Misi Diniyyah Puteri. Diakses 9 Januari 2018, dari http://www.diniyyahputeri.or g/index.php/profil/visi-misi

Diniyyahputeri. 2018. Divisi Otonom Diniyyah Puteri. Diakses 9 Januari 2018, dari http://www.diniyyahputeri.or g/index.php/profil/divisiotonom

Diniyyahputeri. 2018. Fasilitas Diniyyah Puteri. Diakses 9 Januari 2018, dari http://www.diniyyahputeri.or g/index.php/profil/fasilitas

Diniyyahputeri. 2018. Biaya Pendaftaran Fasilitas Diniyyah Puteri. Diakses 9 Januari 2018, dari http://www.diniyyahputeri.or g/index.php/pendaftaran/biay a-pendaftaran

Redaksi. 2016. Diniyyah Puteri Diminati di Malaysia. Diakses 26 September 2018, dari http://harianhaluan.com pada

Setiawan, A. 2014. Prinsip Pendidikan Karakter dalam Islam (Studi Komparasi AlGhazali dan Burhanuddin alZarmiji). Junal Dinamika Ilmu, Vol 13 No 1. 